\title{
KAJIAN TERHADAP PENYELESAIAN SENGKETA PEMBAGIAN HARTA WARISAN ATAS TANAH AKIBAT TIDAK DILAKSANAKANNYA WASIAT OLEH AHLI WARIS DIHUBUNGKAN DENGAN BUKU II KITAB UNDANG-UNDANG HUKUM PERDATA TENTANG BENDA (VAN ZAKEN)
}

\author{
Anita Kamilah dan M. Rendy Aridhayandi \\ Fakultas Hukum Universitas Suryakancana Cianjur \\ E-mail: anita.kamilah@yahoo.co.id
}

\begin{abstract}
Considering the sensitivity of inheritance law, to keep the disputes in the future, there are some heirs who have entrusted that inheritance division is in accordance with their testaments and it is entrusted to the benefiaries.

The analysis result shows that (1) the disputes in inheritance division may come from internal factors and external factors as well. The process of inheritance division rights to land based on testament can be done through testament, (2) the process of inheritance rights of land right based on testament, according to the regulation applicable is Islamic Law Compilation, (3) Settlement performed by the beneficiaries as testament recipients as a result of testament which is not performed is to use settlement in court or out of court.

The conclusion of this reseach is; as one heirs who gives testament should refer to the agreement by the beneficiaries, and the inheritance division should be implemented according to the mandate or testamentary of the heirs during their lives.
\end{abstract}

Keywords: inheritance; disputes testament.

\begin{abstract}
Abstrak
Mengingat sensitifnya bidang hukum warisan ini, untuk menjaga perselisihan dikemudian hari, ada beberapa pewaris yang sudah mengamanatkan pembagian warisan sesuai dengan kehendaknya dan hal tersebut diamanatkan kepada ahli-ahli waris.

Hasil analisis menunjukkan (1) munculnya sengketa dalam pembagian harta warisan dapat berasal dari faktor internal dan dari faktor eksternal. Proses pembagian warisan hak atas tanah dilandasi surat wasiat dapat dilakukan melalui cara testament, (2) proses pembagian warisan hak atas tanah yang dilandasi surat wasiat, sesuai aturan berlaku adalah menurut Kompilasi Hukum Islam, (3) Penyelesaian yang dapat dilakukan para ahli waris penerima wasiat sebagai akibat tidak dilaksanakannya surat wasiat adalah menggunakan cara penyelesaian di pengadilan atau di luar pengadilan.

Kesimpulan, sebagai salah satu pewaris yang memberikan wasiat sebaiknya pelaksanaan pembagian warisan dapat dilaksanakan sebagaimana telah disepakati para ahli warisnya, dan pembagian warisan tersebut harus dilaksanakan sesuai amanat atau wasiat pewaris semasa hidupnya.
\end{abstract}

Kata Kunci: Warisan, Sengketa, Wasiat. 


\section{A. PENDAHULUAN}

Negara Republik Indonesia adalah Negara hukum berdasarkan Pancasila dan Undang-Undang Dasar 1945, yang memiliki tujuan mewujudkan tata kehidupan Negara dan bangsa yang adil dan sejahtera, aman, tentram, dan tertib, serta menjamin kedudukan hukum yang sama bagi warga masyarakat.

Penegasan bahwa Negara hukum adalah cita hukum (rechtsidee) Indonesia yang secara normatif di atur dalam Pasal 1 ayat (3) Undang-Undang Dasar 1945 amandemen ketiga, yang menyebutkan bahwa: "Negara Indonesia adalah Negara hukum (Rechtsstaat) tidak berdasar atas kekuasaan belaka (Machtsstaat)", dan "Pemerintahan berdasar atas sistem konstitusi (hukum dasar) tidak bersifat absolutism (kekuasaan yang tidak terbatas)".1

Dalam konteks di atas, maka menurut M.C Burkens, syarat-syarat dasar rechtsstaat adalah sebagai berikut:

1. Asas legalitas, dimana setiap tindakan pemerintah harus didasarkan atas dasar peraturan perundang-undangan (wettelijkegrondslag), dengan landasan ini undang-undang dalam arti formal dan Undang-Undang Dasar sendiri merupakan tumpuan dasar tindakan pemerintah. Dalam hubungan ini pembentukan undang-undang merupakan bagian penting negara hukum.

2. Pembagian kekuasaan, syarat ini mengandung makna bahwa kekuasaan negara tidak boleh hanya bertumpu pada satu tangan.

3. Hak-hak dasar (grondrechten), dimana hak-hak dasar ini merupakan sasaran perlindungan hukum bagi rakyat dan sekaligus membatasi kekuasaan pembentukan undang-undang.

4. Pengawasan pengadilan, sehingga bagi rakyat tersedia saluran pengadilan yang bebas untuk menguji keabsahan tindakan pemerintah (rechtmatigheidstoetsing). ${ }^{2}$

Lebih lanjut, menurut Imannuel Kant dan F.J. Stahl, kriteria untuk dapat disebut Negara hukum, harus memenuhi unsurunsur sebagai berikut:

1. Jaminan terhadap perlindungan hakhak asasi manusia;

2. Terselenggaranya pemisahan atau pembagian kekuasaan untuk terselenggaranya hak-hak tersebut di atas;

3. Tiap tindakan pemerintah harus dilandasi undang-undang; dan

4. Adanya peradilan administrasi. ${ }^{3}$

Maka melalui konstitusi nasional Indonesia, telah ditetapkan Pasal 28 A-J Undang-Undang Dasar 1945. Dari ketentuan pasal-pasal tersebut, salah satu di antaranya yaitu sesuai Pasal $28 \mathrm{H}$ ayat (4) menyebutkan bahwa "Setiap orang berhak mempunyai hak milik pribadi dan hak milik tersebut tidak boleh diambil alih secara sewenang-wenang oleh siapa pun".

1 Anita Kamilah, Bangun Guna Serah (Build Operate And Transfer/BOT) Membangun Tanpa Harus Memiliki Tanah (Perspektif Hukum Agraria, hukum Perjanjian Dan Hukum Publik, Keni Media, Bandung, 2013, hlm. 1.

2 Philipus M. Hajon, Ide Negara Hukum Dalam Sistem Ketatanegaraan Republik Indonesia, dalam Bagir Manan (Editor) Kedaulatan Rakyat, Hak Asasi Manusia dan Negara Hukum, Gaya Media Pratama, Jakarta, 1996, hlm. 75-76.

3 Padmo Wahjono, Pembangunan Hukum di Indonesia, In-Dhill. Co., Jakarta, 1989, hlm. 151-152. 
Sebagai tindak lanjut dari Konstitusi Nasional Indonesia tersebut, Pasal 36 Undang-Undang No. 39 Tahun 1999 Tentang Hak Asasi Manusia, menyebutkan bahwa "Pada dasarnya setiap orang berhak mempunyai hak milik baik sendiri maupun bersama-sama dengan orang lain untuk pengembangan diri, maupun keluarganya, dan pemilikan hak atas tanah tersebut dapat memberikan manfaat dan kegunaan dalam berbagai aspek kehidupan pemiliknya, baik dalam aspek ekonomi, maupun aspek sosial".

Di dalam kehidupan masyarakat Indonesia, pemilikan hak atas tanah memiliki peranan yang yang sangat penting, hal ini dapat dilihat dari pengertian hak milik itu sendiri, yang bersifat turun temurun, terkuat, dan terpenuh, yang dapat dipunyai orang atas tanah. Dari kata turun temurun tersebut artinya hak atas tanah tersebut dapat diwariskan kepada ahli-ahli warisnya.

Di dalam konsep hukum nasional, hukum waris di atur dalam KUH Perdata bagian $\mathrm{V}$ tentang hukum waris. Harta waris adalah harta peninggalan orang tua untuk anak-anak yang ditinggalkan sebagai penerus atau ahli waris atas harta yang ditinggalkan oleh orang tua yang telah meninggal dunia. ${ }^{4}$

\section{Menurut Hilman Hadikusuma,} di dalam KUH Perdata $(B W)$ tidak ada pasal tertentu yang memberikan pengertian tentang hukum waris, namun demikian Pasal 830 KUH Perdata (BW) menyebutkan bahwa pewarisan hanya berlangsung karena kematian, dengan demikian pengertian hukum waris barat menurut KUH Perdata $(B W)$ ialah tanpa adanya orang yang mati dan meninggalkan harta kekayaan, maka tidak ada masalah pewarisan, sehingga harus ada orang yang meninggal dunia, pertama-tama tentulah apa yang dinamakan kematian alami (naturlijke dood). ${ }^{5}$

Lebih lanjut dalam Pasal $883 \mathrm{KUH}$ Perdata $(B W)$ menyebutkan bahwa adalah sah pula, suatu ketetapan wasiat, dengan mana mengenai sesuatu kebendaan hak pakai hasilnya diberikan kepada orang yang satu, sedangkan hak milik sematamata atas kebendaan itu diberikan kepada orang yang lain.

Hukum waris menurut para sarjana pada pokoknya adalah peraturan yang mengatur perpindahan kekayaan seseorang yang meninggal dunia kepada satu atau beberapa orang lain.

Menurut Pitlo disebutkan bahwa "Hukum waris adalah suatu rangkaian ketentuan-ketentuan dimana berhubungan dengan meninggalnya seseorang, akibat-akibatnya di dalam bidang kebendaan diatur yaitu akibat dari beralihnya harta peninggalan dari seorang yang meninggal kepada ahli waris baik di dalam hubungannya antara keluarga itu sendiri maupun dengan pihak ketiga. Intinya adalah peraturan yang mengatur akibatakibat hukum dari kematian seseorang terhadap harta kekayaan yang berwujud perpindahan kekayaan si pewaris dan akibat hukum perpindahan tersebut bagi

$4 \quad$ Shinta Kencana, Kajian Tentang Perbuatan Melawan Hukum Yang Dilakukan Ahli Waris Dalam Bentuk Pembagian Harta Warisan Tanpa Sepengetahuan Pewaris, Skripsi, Fakultas Hukum Universitas Suryakancana, Cianjur, 2012, hlm. 8.

5 Hilman Hadikusuma, Hukum Waris Indonesia, Citra Aditya Bakti, Bandung, 1993, hlm. 82. 
para ahli waris, baik dalam hubungan antara sesama ahli waris maupun antara para ahli waris dengan pihak ketiga". 6

Lebih lanjut menurut Mohd. Idris Ramulyo dalam bukunya yang berjudul Beberapa Masalah Pelaksanaan Hukum Kewarisan Perdata Barat $(B W)$, disebutkan bahwa "Dari seluruh hukum yang ada dan berlaku dewasa ini di samping hukum perkawinan, maka hukum kewarisan merupakan bagian dari Hukum Kekeluargaan, memegang peranan yang sangat penting bahkan menentukan dan mencerminkan sistem kekeluargaan yang berlaku dalam masyarakat itu".7

Seperti diungkapkan Hazairin dari seluruh hukum, maka hukum perkawinan dan kewarisanlah yang menentukan dan mencerminkan sistem kekeluargaan yang berlaku dalam masyarakat. Hal ini disebabkan, hukum kewarisan itu sangat erat dengan ruang lingkup kehidupan manusia. Bahwa setiap manusia pasti akan mengalami suatu peristiwa yang sangat penting dalam hidupnya yang merupakan peristiwa hukum dan lajim disebut meninggal dunia.

Selain hukum waris barat yang tertuang di dalam Kitab Undang-undang Hukum Perdata, hukum yang mengatur pembagian harta warisan yaitu:

1. Hukum Waris Islam merupakan ketentuan Al-quran dan Hadist. Penggunaan hukum Waris Islam tergantung pada keimanan seseorang, dengan demikian, maka keyakinan akan keimanan merupakan faktor utama.
2. Hukum Waris Adat yang beraneka ragam, tergantung di lingkungan mana masalah warisan itu terbuka. Sebagaimana diketahui di Indonesia faktor etnis mempengaruhi berlakunya aneka hukum adat yang tentunya dalam masalah warisan pun mempunyai corak sendiri-sendiri.

Selanjutnya di dalam konsep hukum nasional Indonesia, masalah pewarisan sebagai hukum yang mengatur peralihan kekayaan dari pewaris kepada ahli warisnya merupakan bidang hukum yang bersifat sensitif, oleh karena itu pembagian terhadap harta warisan tersebut dapat dilakukan berdasarkan Hukum Islam, Hukum Adat, serta atas dasar kesepakatan para pihak.

Keluarga adalah faktor paling penting dalam kehidupan, dimana keluarga menjadi tempat dalam anggotanya berinteraksi satu sama lain di sekitar lingkungan sehari-hari, dan dapat diketahui bahwa dalam suatu keluarga terdapat komponen anak yang memiliki peran penting menjadi penerus keluarga atau dapat dikatakan sebagai ahli waris dan penerus harta yang menjadi peninggalan orang tuanya kelak setelah orang tuanya meninggal. Agar harta peninggalan tersebut terjaga dan dapat digunakan dengan baik tanpa menimbulkan sengketa bagi penerusnya kelak, maka pembagiannya harus sesuai hukum yang berlaku.

Berlandaskan pada hal tersebut, dalam suatu keluarga dapat dibenarkan untuk melakukan pembagian harta warisan

6 A. Pitlo, Hukum Waris Menurut Kitab Undang-undang Hukum Perdata Belanda, terjemahan M. Isa Arief, Intermasa, Jakarta, 1979, hlm. 76.

$7 \quad$ M. Idris Ramulyo, Perbandingan Pelaksanaan Hukum Kewarisan Islam dengan Kewarisan Kitab UndangUndang Hukum Perdata (BW), Sinar Grafika, Jakarta, 1994, hlm. 47. 
dengan didasarkan pada kesepakatan dari pewaris maupun ahli waris, salah satu bentuknya dengan cara melakukan pembagian warisan dengan jumlah yang sama tanpa memperhatikan status penerima warisan apakah seorang lakilaki maupun perempuan.

Berdasarkan kenyataanyangada dalam masyarakat dan pada kehidupan seharihari, sering terjadi sengketa dan masalahmasalah yang timbul ketika pembagian harta warisan dilaksanakan. Adapun yang dimaksud sengketa menurut Duene RuthHefelbower adalah kondisi yang terjadi ketika dua pihak atau lebih menganggap ada perbedaan posisi yang tidak selaras, tidak cukup sumber dan tindakan salah satu pihak menghalangi, atau mencampuri atau dalam beberapa hal membuat tujuan pihak lain kurang berhasil. ${ }^{8}$ Penyelesaian sengketa berkenaan dengan waris dapat dilakukan dengan cara hukum waris Islam, hukum waris barat dan hukum waris adat.

Bahkan mengingat sensitifnya bidang hukum warisan ini, untuk menjaga perselisihan dikemudian hari, ada beberapa pewaris yang sudah mengamanatkan pembagian warisan tersebut sesuai dengan kehendaknya dan hal tersebut diamanatkan kepada ahli-ahli waris.

Jika pelaksanaan pembagian warisan tersebut, dapat dilaksanakan sebagaimana telah disepakati para ahli warisnya, bahkan pembagian warisan tersebut telah dilaksanakan sesuai amanat atau wasiat pewaris semasa hidupnya, maka tujuan pewarisan tersebut telah dapat dilaksanakan dengan baik. Namun seringkali ditemui suatu persoalan, ketika pewaris sudah benar-benar meninggal, para ahli waris tidak melaksanakan isi wasiat tersebut, yang kemudian menimbulkan konflik atau persengketaan yang apabila tidak diselesaikan dengan baik dapat berdampak pada terganggunya hubungan kekeluargaan di antara pewaris. Dalam jurnal ini penulis membatasi bahasan dengan analisis mengenai: (1) Latar belakang munculnya sengketa dalam pembagian harta warisan; (2) Proses pembagian warisan hak atas tanah yang di landasi surat wasiat; (3) Cara penyelesaian sengketa yang dapat dilakukan para ahli waris penerima wasiat sebagai akibat tidak dilaksanakannya surat wasiat

Berkenaan dengan persoalan tersebut, menarik minat Penulis untuk mengkajinya dan menuangkannya dalam bentuk jurnal dengan judul: "KAJIAN TERHADAP PENYELESAIAN SENGKETA PEMBAGIAN HARTA WARISAN ATAS TANAH AKIBAT TIDAK DILAKSANAKANNYA WASIAT OLEH AHLI WARIS DIHUBUNGKAN DENGAN BUKU II KITAB UNDANGUNDANG HUKUM PERDATA TENTANG BENDA (VAN ZAKEN)".

\section{B. PEMBAHASAN}

Ahli Hukum Indonesia telah mencoba memberikan rumusan mengenai pengertian hukum warisyang disusun dalam bentuk batasan (definisi). Sebagai pedoman dalam upaya memahami pengertian hukum waris secara utuh, ada beberapa definisi mengenai waris dan hukum waris yang diberikan oleh beberapa sarjana.

Wirjono Prodjodikoro, memberikan rumusan warisan adalah soal apakah

8 Dhaniasashari.blogspot.com, diunduh pada Rabu, 17 April 2013, jam 16.00 WIB. 
dan bagaimanakah berbagai hak-hak dan kewajiban-kewajiban tentang kekayaan seseorang pada waktu ia meninggal dunia akan beralih kepada orang yang masih hidup. ${ }^{9}$

Kemudian, Soepomo memberikan rumusan hukum waris, yaitu bahwa:

"Hukum waris memuat perturanperaturan yang mengatur proses meneruskan serta mengoperkan barang-barang harta benda dan barang-barang yang tidak berwujud benda (immateriele goederen) dari suatu angkatan manusia (generatie) kepada turunannya. Proses ini telah mulai pada waktu orang tua masih hidup. Proses tersebut tidak menjadi "akut" oleh sebab orang tua meninggal dunia. Memang meninggalnya bapak atau ibu adalah suatu peristiwa yang penting bagi proses itu, akan tetapi sesungguhnya tidak mempengaruhi secara radikal proses penerusan dan pengoperan harta benda dan harta bukan benda tersebut". ${ }^{10}$

\section{Lebihlanjut, R.Santoso Pudjosubroto,} mengemukakan bahwa: "Hukum warisan adalah hukum yang mengatur apakah dan bagaimanakah hak-hak dan kewajibankewajiban tentang harta benda seseorang pada waktu ia meninggal dunia akan beralih kepada orang lain yang masih hidup".11
Seperti halnya Wirjono Prodjodikoro yang menggunakan istilah "hukum warisan", R. Santoso Pudjosubroto juga memakai istilah serupa dalam rumusannya, yakni menggunakan istilah "hukum warisan" untuk menyebut "hukum waris".

B. Ter Haar dalam bukunya "Asasasas dan Susunan Hukum Adat" yang dialihbahasakan oleh K. Ng. Soebakti Poesponoto memberikan rumusan hukum waris sebagai berikut: "Hukum waris adalah aturan-aturan hukum yang mengenai cara bagaimana dari abad ke abad penerusan dan peralihan dari harta kekayaan yang berwujud dan tidak berwujud dari generasi ke generasi". ${ }^{12}$

Dari rumusan tentang waris atau hukum waris di atas, dapat disimpulkan bahwa:

"Hukum waris, adalah kumpulan peraturan, yang mengatur hukum mengenai kekayaan karena wafatnya seseorangyaitu mengenai pemindahan kekayaan yang ditinggalkan oleh si mati dan akibat dari pemindahan ini bagi orang-orang yang memperolehnya, baik dalam hubungan antara mereka dengan mereka, maupun dalam hubungan antara mereka dengan pihak ketiga".13

Suatu hal yang perlu diperhatikan, yaitu walaupun terdapat rumusan dan uraian yang beragam tentang hukum waris, pada umumnya para sarjana

\footnotetext{
9 Wirjono Prodjodikoro, Hukum Perdata Tentang Persetujuan Persetujuan Tertentu, Sumur Bandung, Bandung, 1991, hlm. 8.

10 Soepomo, Bab-bab Tentang Hukum Adat, Penerbitan Universitas, Jakarta, 1996, hlm. 72-73.

11 R. Santoso Pudjosubroto, Masalah Hukum Sehari-hari, Hien Hoo Sing, Yogyakarta, 1964, hlm. 8.

12 K. Ng. Soebakti Poesponoto, Azas Dan Susunan Hukum Adat, Pradnya Paramita, Jakarta, 1960, hlm. 197.

13 A. Pitlo, Hukum Waris Menurut..., Op.Cit., hlm. 1.
} 
hukum sependapat bahwa, "Hukum waris itu merupakan perangkat kaidah yang mengatur tentang cara atau proses peralihan harta kekayaan dari pewaris kepada ahli waris atau para ahli warisnya". Kemudian dalam Kamus Hukum, pengertian warisan adalah harta peninggalan yang berupa barangbarang atau hutang dari orang yang meninggal, yang seluruhnya atau sebagian ditinggalkan atau diberikan kepada ahli waris atau orang-orang yang telah ditetapkan menurut surat wasiat. ${ }^{14}$

Menurut Hukum Islam, mawaris berarti hal-hal yang berhubungan dengan waris dan warisan. Ilmu yang mempelajari mawaris disebut ilmu faraid. Ilmu artinya pengetahuan dan faraid berarti bagian-bagian yang tertentu. Jadi, ilmu faraid berarti ilmu pengetahuan yang menguraikan cara membagi harta peninggalan seseorang kepada ahli waris yang berhak menerimanya. ${ }^{15}$ Ilmu faraid, sebagai salah satu cabang ilmu pengetahuan Islam, bersumber dari AlQuran dan Hadist. Tujuan diturunkannya ilmu faraid adalah agar pembagian warisan dilakukan secara adil, tidak ada ahli waris yang dirugikan sehingga tidak akan terjadi perselisihan atau perpecahan di antara ahli waris karena pembagian warisan.

Berkaitan dengan hal tersebut, di bawah ini akan disebutkan beberapa ayat suci Al-Quran yang merupakan sendi utama pengaturan warisan dalam Islam. Ayat-ayat tersebut secara langsung menegaskan perihal pembagian harta warisan di dalam Al-Quran, masing-masing tercantum dalam surat An-Nissa (Q.S. 4: 7, 11,12, 33 dan 176), surat Al-Baqarah (Q.S. 2), dan terdapat pula pada dalam surat Al- Ahzab (Q.S. 28). Arti waris dalam Hukum Islam berasal dari bahasa Arab yang berarti peninggalan-peninggalan yang ditinggalkan oleh seseorang yang meninggal dunia. ${ }^{16}$

Selain itu, ada yang menyebutkan istilah Al-miirats, dalam bahasa Arab adalah bentuk mashdar (inisiatif) dari kata waritsa-yaritsu-irtsan-miiraatsan. Maknanya menurut bahasa ialah "berpindahnya sesuatu dari seseorang kepada orang lain", atau "dari suatu kaum kepada kaum lain". ${ }^{17}$

Selanjutnya menurut Kompilasi Hukum Islam (KHI) buku II tentang hukum kewarisan, bab I ketentuan umum Pasal 171 menyebutkan bahwa hukum kewarisan adalah hukum yang mengatur tentang pemindahan hak pemilikan harta peninggalan (tirkah) pewaris, menentukan siapa-siapa yang berhak menjadi ahli waris dan berapa baginya masing-masing.

Menurut Kitab Undang-Undang Hukum Perdata $(B W)$, hukum waris adalah hukum yang mengatur mengenai apa yang harus terjadi dengan harta kekayaan seseorang yang telah meninggal dunia, dengan perkataan lain mengatur peralihan harta kekayaan yang ditinggalkan oleh seseorang yang telah meninggal dunia beserta akibat-akibatnya bagi ahli waris.

14 J.C.T. Simorangkir, S.H., dkk, Kamus Hukum..., Op.Cit., hlm. 186.

15 Syamsuri, Pendidikan Agama Islam SMA Jilid 3 Untuk Kelas XII, Erlangga, Jakarta, 2007, hlm. 140.

16 Tamakiran S, Asas-Asas Hukum Waris Menurut Tiga Sistem Hukum, CV. Pionir Jaya, Bandung, 2000, hlm. 84.

17 Mustofa Haffas, Hukum Waris Islam, Refika Aditama, Bandung, 2002, hlm. 83. 
Menurut Ter Haar, yang berpendapat bahwa: "...hukum waris adat itu meliputi aturan-aturan hukum yang bertalian dengan proses dari abad ke abad yang menarik perhatian, ialah proses penerusan dan peralihan kekayaan material dan immaterial dari turunan keturunannya".18

Di dalam membicarakan hukum waris, maka ada 3 (tiga) hal yang perlu mendapat perhatian, di mana ketiga hal ini merupakan unsur-unsur pewarisan, yaitu:

\section{Orang yang meninggal dunia/ pewaris/erflater.}

Pewaris ialah orang yang meninggal dunia dengan meninggalkan hak dan kewajiban kepada orang lain yang berhak menerimanya. Menurut Pasal 830 Kitab Undang-Undang Hukum Perdata $(B W)$, pewarisan hanya berlangsung karena kematian. Kemudian, menurut ketentuan Pasal 874 Kitab Undang-Undang Hukum Perdata $(B W)$, segala harta peninggalan seorang yang meninggal dunia adalah kepunyaan sekalian ahli warisnya menurut undang-undang sekedar terhadap itu dengan surat wasiat tidak telah diambil setelah ketetapan yang sah. Dengan demikian, menurut Kitab Undang-Undang Hukum Perdata $(B W)$ ada dua macam waris, yaitu waris $a b$ intestate (tanpa wasiat) dan waris wasiat atau testamentair erfrecht.

\section{Ahli waris yang berhak menerima harta kekayaan itu/erfgenaam.}

Ahli waris yaitu orang yang masih hidup yang oleh hukum diberi hak untuk menerima hak dan kewajiban yang ditinggal oleh pewaris. Lalu bagaimana dengan bayi yang ada dalam kandungan?, menurut Pasal 2 Kitab Undang-Undang Hukum Perdata $(B W)$, anak yang ada dalam kandungan dianggap sebagai telah dilahirkan bilamana keperluan si anak menghendaki. Jadi, dengan demikian seorang anak yang ada dalam kandungan, walaupun belum lahir dapat mewarisi karena dalam pasal tersebut hukum membuat fiksi, seakan-akan anak sudah dilahirkan. Ahli waris terdiri dari:

a. Ahli waris menurut undang-undang (abintestato).

Ahli waris ini didasarkan atas hubungan darah dengan si pewaris atau para keluarga sedarah. Ahli waris ini terdiri dari 4 (empat) golongan, yaitu:

1) Golongan I, terdiri dari anak-anak, suami (duda) dan istri (janda) si pewaris;

2) Golongan II, terdiri dari bapak, ibu (orang tua), saudara-saudara si pewaris;

3) Golongan III, terdiri dari keluarga sedarah bapak atau ibu lurus ke atas (seperti: kakek, nenek, baik garis atau pancer bapak atau ibu) si pewaris;

4) Golongan IV, terdiri dari sanak keluarga dari pancer samping (seperti: paman, bibi).

b. Ahli waris menurut wasiat (testamentair erfrecht).

Ahli waris ini didasarkan atas wasiat yaitu dalam Pasal 874 Kitab UndangUndang Hukum Perdata $(B W)$, dimana setiap orang yang diberi wasiat secara sah oleh pewaris wasiat, terdiri atas:

18 Eman Suparman, Hukum Waris Indonesia Dalam Perspektif Islam, Adat dan BW, Refika Aditama, Bandung, 2005, hlm. 67. 
1) Testamentair erfgenaam.

yaitu ahli waris yang mendapat wasiat yang berisi suatu erfstelling (petunjukkan satu atau beberapa ahli waris untuk mendapat seluruh atau sebagian harta peninggalan);

2) Legataris/mendapat wasiat.

yaitu ahli waris karena mendapat wasiat yang isinya menunjuk seseorang untuk mendapat beberapa hak atas satu atau beberapa macam harta waris, hak atas seluruh dari satu macam benda tertentu, hak untuk memungut hasil dari seluruh atau sebagian dari harta waris.

Jadi, dengan demikian ada tiga dasar untuk menjadi ahli waris, yaitu, ahli waris atas dasar hubungan darah, ahli waris atas dasar perkawinan dengan si pewaris, dan ahli waris atas dasar wasiat.

\section{Harta Waris.}

Menurut Pasal 499 KUH Perdata, disebutkan bahwa: "Benda adalah tiaptiap barang dan tiap-tiap hak, yang dapat dikuasai oleh hak milik". Selain itu, secara yuridis pengertian benda ialah segala sesuatu yang dapat menjadi objek eigendom (hak milik). Barang-barang bergerak, dan barang-barang tidak bergerak. Benda bergerak adalah benda yang menurut sifatnya dapat dipindahkan sesuai Pasal 509 Kitab Undang-Undang Hukum Perdata $(B W)$. Benda bergerak karena ketentuan undang undang adalah hak-hak yang melekat pada benda bergerak sesuai Pasal 511 Kitab UndangUndang Hukum Perdata $(B W)$, misalnya hak memungut hasil atas benda.
Di antara macam-macam benda-benda sebagaimana disebutkan di atas, tanah sebagai benda tidak bergerak, merupakan salah satu objek pewarisan.

Merujuk Pasal 20 ayat (1) UndangUndang No. 5 Tahun 1960 Tentang Peraturan Dasar Pokok-pokok Agraria disebutkan bahwa Hak Milik adalah: "hak turun-temurun, terkuat dan terpenuh yang dapat dipunyai orang atas tanah, dengan mengingat ketentuan Pasal 6".

Kemudian, sesuai Pasal 20 ayat (2) Undang-Undang No. 5 Tahun 1960 Tentang Peraturan Dasar Pokok-pokok Agraria disebutkan bahwa hak milik dapat beralih dan dialihkan kepada pihak lain.

Peralihan hak milik atas tanah dapat terjadi karena perbuatan hukum dan peristiwa hukum. Peralihan hak milik atas tanah karena perbuatan hukum dapat terjadi apabila pemegang hak milik atas tanah dengan sengaja mengalihkan hak yang dipegangnya kepada pihak lain. Peralihan hak milik atas tanah karena peristiwa hukum, terjadi apabila pemegang Hak milik atas tanah meninggal dunia, maka dengan sendirinya atau tanpa adanya suatu perbuatan hukum disengaja dari pemegang hak, hak milik beralih kepada ahli waris pemegang hak.

Penulis belum menemukan definisi sengketa waris secara utuh, namun penulis mencoba memberikan referensi definisi mengenai sengketa waris. Menurut Kamus Hukum yang disusun oleh J.C.T. Simorangkir, Rudy T. Erwin, dan J.T Prasetyo mendefinisikan pengertian sengketa adalah persoalan atau perkara. ${ }^{19}$ Warisan adalah harta peninggalan yang

19 J.C.T. Simorangkir, dkk, Kamus Hukum..., Op.Cit., hlm. 157. 
berupa barang-barang atau hutang dari orang yang meninggal, yang seluruhnya atau sebagian ditinggalkan atau diberikan kepada para ahli waris atau orang-orang yang telah ditetapkan menurut surat wasiat. $^{20}$

Menurut Kamus Hukum Indonesia yang disusun oleh B.N. Marbun mendefinisikan pengertian sengketa adalah pertikaian, perselisiahan, sesuatu yang menyebabkan perbedaan pendapat, pertengkaran, perbantahan, yang biasa meningkat menjadi sengketa hukum. ${ }^{21}$ Waris adalah orangyang berhak menerima harta pusaka dari orang yang telah meninggal. ${ }^{22}$

Menurut Peraturan Mahkamah Agung Republik Indonesia Nomor 02 Tahun 2003 Tentang Prosedur Mediasi Di Pengadilan, pada bab I ketentuan umum Pasal 1 angka 9 menyebutkan bahwa sengketa publik adalah sengketa-sengketa di bidang lingkungan hidup, hak asasi manusia, perlindungan konsumen, pertanahan dan perburuhan yang melibatkan kepentingan banyak buruh. ${ }^{23}$

Lembaga Penyelesaian Sengketa Waris dapat dilakukan di pengadilan/litigasi, (1) Peradilan Agama; (2) Peradilan Perdata. Juga dapat dilakukan di luar pengadilan/ non litigasi, (1) Arbitrase; (2) Konsiliasi;
(3) Konsultasi; dan Lembaga Hukum AdatPlus (LHA- Plus). ${ }^{24}$

Berdasarkan hasil riset Asni Zubair, bahwamelaluipendekatanAnthropological Study of Law, diungkapkan bahwa, rata-rata penyebab timbulnya konflik/ sengketa dalam pembagian harta warisan dapat berasal dari faktor internal, seperti adanya hibah orang tua kepada bakal ahli waris, tetapi tidak adil dan tidak disertai akta hibah, pasangan suami istri (sebagai bakal pewaris) yang tidak memiliki anak atau keturunan, keserakahan ahli waris, ketidakpahaman ahli waris, kekeliruan dalam menegakkan siri' dan tertundanya pembagian harta warisan. Kemudian, penyebab konflik atau sengketa yang berasal dari faktor eksternal, seperti: adanya anak angkat yang diberi hibah oleh orang tua angkatnya, hadirnya provokator, dan harta warisan dipinjamkan kepada kerabat yang bukan ahli waris dan tidak dikembalikan. ${ }^{25}$

Oleh karena itu, latar belakang munculnya sengketa dalam pembagian harta warisan karena adanya ketidakadilan, ketidakpastian, dan ketidaktertiban. Namun demikian, perlu pula dipikirkan, adalah sungguh baik apabila manusia dapat menghindar dari sengketa kemudian hari. Sehubungan

20 Ibid., hlm. 186.

21 B.N Marbun, Kamus Hukum Indonesia, Edisi Kedua Direvisi, Pustaka Sinar Harapan, Jakarta, 2009, hlm. 311-312.

$22 \quad$ Ibid., hlm. 360.

23 Sentosa Sembiring (him), Himpunan Peraturan Perundang-Undangan Republik Indonesia Tentang Penyelesaian Sengketa Di Luar Pengadilan (Arbitrase Dan Mediasi), Nuansa Aulia, Bandung, 2008, hlm. 84.

24 Darwinsyah Minin, Penyelesaian Sengketa Non-Litigasi (Dasar-bentuk- Teknik-Proses Dan Pelaksanaan), disampaikan dalam Kuliah Umum di Fakultas Hukum Universitas Suryakancana pada tanggal 27 April 2013, Cianjur.

25 Asni Zubair, http://rouf-artikel.blogspot.com/2012/11/penyelesaian-hukum-waris.html, Disertasi Uin Sunan Kalijaga, 2013, diunduh pada Jumat, 3 Mei, jam 14.30 WIB. 
dengan itu, setiap langkah yang akan ditempuh perlu perencanaan yang baik, maka dalam konteks hukum dapat diduga akan semakin menempatkan peran pengacara atau konsultan hukum dalam porsi penting. Tindakan perencanaan secara baik yang diletakkan pada suatu produk perundang-undangan, pada dasarnya merupakan penciptaan kondisi ke arah pencegahan dan penghindaran terjadinya perkara di depan pengadilan, dan perkara merupakan jalan penyelesaian terakhir. ${ }^{26}$

Adapun ahli waris menurut wasiat (testamentair erfrecht).

Terdiri atas: (1) Testamentair erfgenaam yaitu ahli waris yang mendapat wasiat yang berisi suatu erfstelling (petunjukkan satu atau beberapa ahli waris untuk mendapat seluruh atau sebagian harta peninggalan); (2) Legataris yaitu ahli waris karena mendapat wasiat yang isinya menunjuk seseorang untuk mendapat beberapa hak atas satu atau beberapa macam harta waris, hak atas seluruh dari satu macam benda tertentu, hak untuk memungut hasil dari seluruh atau sebagian dari harta waris.

Cara penyelesaian yang dapat dilakukan para ahli waris adalah:

\section{Penyelesaian Sengketa Pengadilan.}

Berkaitan dengan penyelesaian sengketa di pengadilan, maka di dalam sistem hukum Indonesia perlu terlebih dahulu disinggung tentang peran
Mahkamah Agung (MA) sebagai institusi hukum menurut Undang-Undang Dasar Republik Indonesia Tahun 1945. Mahkamah Agung (MA) adalah lembaga tinggi negara dalam sistem ketatanegaraan Indonesia yang merupakan pemegang kekuasaan kehakiman bersama-sama dengan Mahkamah Konstitusi (MK). MA membawahi badan peradilan dalam lingkungan pengadilan umum, lingkungan peradilan agama, lingkungan peradilan militer, lingkungan peradilan tata usaha negara. Peradilan umum pada tingkat pertama dilakukan oleh pengadilan negeri, pada tingkat banding dilakukan oleh pengadilan tinggi dan pada tingkat kasasi dilakukan oleh mahkamah agung. Peradilan agama pada tingkat pertama dilakukan oleh Pengadilan Agama, pada tingkat banding dilakukan oleh Pengadilan Tinggi Agama dan pada tingkat kasasi dilakukan oleh Mahkamah Agung. Peradilan militer pada tinggat pertama dilakukan oleh Pengadilan Militer, pada tingkat banding dilakukan oleh Pengadilan Tinggi Militer dan pada tingkat kasasi dilakukan oleh Mahkamah Agung. Peradilan Tata Usaha Negara pada tingkat pertama dilakukan oleh Pengadilan Tata Usaha Negara, pada tingkat banding dilakukan oleh Pengadilan Tinggi Tata Usaha Negara dan pada tingkat kasasi dilakukan oleh Mahkamah Agung. ${ }^{27}$

Masing-masing badan peradilan ini mempunyai kewenangan tersendiri sesuai dengan lingkup kewenangan yang diberikan oleh undang-undang dan merupakan

26 Lawrence S. Clark And Peter D. Kinder, Law And Business, Third Ed, Mc. Graw Hill Inc, London, 1991, hlm. 2.

27 M. Yahya Harahap, Beberapa Tinjauan Mengenai Sistem Peradilan Dan Penyelesaian Sengketa, Cet. Ke- 1, Citra Aditya Bakti, Bandung, 1997, hlm. 73. 
kewenangan yang absolut bagi badan peradilan tersebut.

Kewenangan yang absolute adalah, badan peradilan manakah yang berwenang untuk mengadili suatu sengketa perdata. Apakah sengketa yang terjadi merupakan kewenangan pengadilan negeri atau pengadilan agama atau pengadilan tata usaha negara, contohnya: masalah perceraian bagi orang Islam merupakan kewenangan pengadilan agama untuk memeriksa, mengadili, dan memutuskannya. Sedangkan kalau menyangkut keputusan badan/pejabat tata usaha negara merupakan kewenangan pengadilan tata usaha negara.

\section{Penyelesaian Sengketa Di luar Pengadilan.}

Tidak dapat dipungkiri bahwa dewasa ini aspirasi untuk mengembangkan Alternative dispute resolution (ADR) semakin banyak. Alternative dispute resolution (ADR) memungkinkan penyelesaian sengketa secara informal, sukarela, dengan kerjasama langsung antara kedua belah pihak yang menuju pada pemecahan sengketa yang saling menguntungkan. Dukungan dari masyarakat bisnis dapat dilihat dari klausul perjanjian dalam berbagai kontrak belakangan ini. Saat ini kaum bisnis Indonesia sudah biasa mencantumkan klausul Alternative dispute resolution (ADR) pada hampir setiap kontrak yang dibuatnya. Contoh klausul Alternative dispute resolution (ADR) yang tercantum dalam kontrak adalah: "Semua sengketa yang mungkin timbul antara kedua belah pihak berdasarkan perjanjian ini, akan diselesaikan dengan musyawarah oleh para pihak dan hasilnya akan dibuat secara tertulis. Jika sengketa tidak dapat diselesaikan dengan musyawarah, maka dari para pihak sepakat untuk membawa perkaranya ke pengadilan".

Keterlibatan pihak ketiga dalam Alternative dispute resolution (ADR) adalah dalam rangka mengusahakan agar para pihak mencapai sepakat untuk menyelesaiakan sengketa yang timbul. Memang ada perbedaan antara mediasi, konsolidasi dan Alternative dispute resolution (ADR). Perbedaannya terletak pada aktif tidaknya pihak ketiga dalam mengusahakan para pihak untuk menyelesaikan sengketa. maka Alternative dispute resolution (ADR) tidak akan dapat terlaksana. Kesukarelaan disini meliputi kesukarelaan terhadap mekanisme penyelesaiannya dan kesukarelaan isi kesepakatan. ${ }^{28}$

Secara etimologis, musyawarah berasal dari kata arab "syawara" yang bermakna mengeluarkan madu dari sarang lebah. Makna ini kemudian berkembang sehingga mencakup segala sesuatu yang dapat diambil atau dikeluarkan dari yang lain, termasuk bermakna pendapat.

Cara penyelesaian melalui arbitrase dapat dilakukan melalui arbitrase nasional yaitu Badan Arbitrase Nasional Indonesia (BANI), arbitrase ad hoc, maupun arbitrase asing. ${ }^{29}$

28 M. Juliadi Razali, Penyelesaian Sengketa Melalui Mediasi Sebagai Perwujudan Asas Peradilan Sederhana, Cepat, Dan Biaya Ringan, Disertasi UNPAR, 2011, hlm. 111-112.

29 Ibid., hlm. 57. 
Dari cara penyelesaian sengketa di pengadilan dan penyelesaian di luar pengadilan, maka cara penyelesaian di luar pengadilanlah yang mempunyai atau berlatar belakang Indonesian Legal Culture (musyawarah, komunal dan atau consensus kolektif) atau yang lebih mengedepankan asas musyawarah untuk mufakat mencapai tujuan kedamaian. $^{30}$ Menurut Cristopher W Moore mengemukakan keuntungan penyelesaian sengketa dengan menggunakan Alternative dispute resolution (ADR) adalah:

a. Sifat kesukarelaan dalam proses;

b. Prosedur yang cepat;

c. Keputusan non judicial;

d. Prosedur rahasia (confidential);

e. Fleksibilitas yang lebih besar dalam merancang syarat-syarat penyelesaian masalah;

f. Hemat waktu dan biaya;

g. Tinggi kemungkinan untuk melaksanakan kesepakatan. ${ }^{31}$

\section{PENUTUP}

Berdasarkan hasil penelitian yang Penulis lakukan, maka selanjutnya Penulis menarik kesimpulan kemudian memberikan rekomendasi yang diharapkan dapat bermanfaat bagi semua pihak. Adapun kesimpulan tersebut antara lain:

1. Latar belakang munculnya sengketa dalam pembagian harta warisan dapat berasal dari faktor internal, seperti adanya hibah orang tua kepada bakal ahli waris, tetapi tidak adil dan tidak disertai akta hibah, pasangan suami istri (sebagai bakal pewaris) yang tidak memiliki anak atau keturunan, keserakahan ahli waris, ketidakpahaman ahli waris, kekeliruan dalam menegakkan siri' dan tertundanya pembagian harta warisan. Selain itu, fakta penyebab konflik atau sengketa yang bersumber dari faktor eksternal, seperti: adanya anak angkat yang diberi hibah oleh orang tua angkatnya, hadirnya provokator, dan harta warisan dipinjamkan kepada kerabat yang bukan ahli waris dan tidak dikembalikan.

2. Proses pembagian warisan hak atas tanah yang dilandasi surat wasiat, sesuai aturan berlaku adalah menurut Kompilasi Hukum Islam, yang dapat dirujuk dari pasal-pasal sebagai berikut:

a. Pasal 194 ayat (2), menyebutkan bahwa harta benda yang diwasiatkan harus merupakan hak dari pewasiat;

b. Pasal 195 ayat (1), menyebutkan bahwa wasiat dilakukan secara lisan di hadapan dua orang saksi, atau tertulis di hadapan dua orang saksi, atau di hadapan notaris;

c. Pasal 195 ayat (3), menyebutkan bahwa wasiat kepada ahli waris hanya berlaku bila disetujui oleh semua ahli waris;

d. Pasal 200, menyebutkan bahwa harta wasiat yang berupa barang tak bergerak, bila karena suatu

30 Darwinsyah Minin, Penyelesaian Sengketa...Op.Cit,.

31 Dedi Mulyadi, Penyelesaian Sengketa Lingkungan Hidup Di Luar Pengadilan, Materi Kuliah ADR di Fakultas Hukum Universitas Suryakancana, Cianjur, 2011, hlm. 2. 
sebab yang sah mengalami penyusutan atau kerusakan yang terjadi sebelum pewasiat meninggal dunia, maka penerima wasiat hanya akan menerima harta yang tersisa;

e. Pasal 204 ayat (1), menyebutkan bahwa Jika pewasiat meninggal dunia, maka surat wasiat yang tertutup dan disimpan pada notaris, dibuka olehnya di hadapan ahli waris, disaksikan dua orang saksi dan dengan membuat berita acara pembukaan surat wasiat itu;

f. Pasal 204 ayat (2), menyebutkan bahwa Jika surat wasiat yang tertutup disimpan bukan pada notaris, maka penyimpan harus menyerahkan kepada notaris setempat atau kantor urusan agama tersebut membuka sebagaimana ditentukan dalam ayat (1) pasal ini;

g. Pasal 204 ayat (3), menyebutkan bahwa Setelah semua isi serta maksud surat wasiat itu diketahui maka oleh notaris atau kantor urusan agama diserahkan kepada penerima wasiat guna penyelesaian selanjutnya.

3. Penyelesaian yang dapat dilakukan para ahli waris penerima wasiat sebagai akibat tidak dilaksanakannya surat wasiat adalah menggunakan cara penyelesaian di pengadilan atau di luar pengadilan.

Adapun saran tersebut antara lain:

1. Sebagai penghargaan terhadap pewaris yang memberikan wasiat sebaiknya pelaksanaan pembagian warisan dapat dilaksanakan sebagaimana telah disepakati para ahli warisnya, dan pembagian warisan tersebut harus dilaksanakan sesuai amanat atau wasiat pewaris semasa hidupnya.

2. Hendaknya dalam pembagian warisan para ahli waris menghindari dari konflik/sengketa waris, karena dapat berdampak pada terganggunya hubungan kekeluargaan di antar pewaris.

3. Penyelesaian sengketa waris dapat diselesaikan melalui pengadilan/ di luar pengadilan, namun demikian sebaiknya penyelesaian sengketa waris dilakukan di luar pengadilan.

\section{DAFTAR PUSTAKA}

\section{Buku}

A. Pitlo, Hukum Waris Menurut Kitab Undang-undang Hukum Perdata Belanda, terjemahan M. Isa Arief, Intermasa, Jakarta, 1979.

Anita Kamilah, Bangun Guna Serah (Build Operate And Transfer/BOT) Membangun Tanpa Harus Memiliki Tanah (Perspektif Hukum Agraria, hukum Perjanjian Dan Hukum Publik, Keni Media, Bandung, 2013.

Eman Suparman, Hukum Waris Indonesia Dalam Perspektif Islam, Adat dan BW, Refika Aditama, Bandung, 2005.

Hilman Hadikusuma, Hukum Waris Indonesia, Citra Aditya Bakti, Bandung, 1993. 
K. Ng. Soebakti Poesponoto, Azas Dan Susunan Hukum Adat, Pradnya Paramita, Jakarta, 1960.

M. Idris Ramulyo, Perbandingan Pelaksanaan Hukum Kewarisan Islam dengan Kewarisan Kitab UndangUndang Hukum Perdata (BW), Sinar Grafika, Jakarta, 1994.

M. Yahya Harahap, Beberapa Tinjauan Mengenai Sistem Peradilan Dan Penyelesaian Sengketa, Cet. Ke-1, Citra Aditya Bakti, Bandung, 1997.

Mustofa Haffas, Hukum Waris Islam, Refika Aditama, Bandung, 2002.

Padmo Wahjono, Pembangunan Hukum di Indonesia, In-Dhill. Co., Jakarta, 1989.

Philipus M. Hajon, Ide Negara Hukum Dalam Sistem Ketatanegaraan Republik Indonesia, dalam Bagir Manan (Editor) Kedaulatan Rakyat, Hak Asasi Manusia dan Negara Hukum, Gaya Media Pratama, Jakarta, 1996.

R. Santoso Pudjosubroto, Masalah Hukum Sehari-hari, Hien Hoo Sing, Yogyakarta, 1964.

Ronny Hanitijo Soemitro, Metodologi Penelitian Hukum Dan Jurimetri, Ghalia Indonesia, Jakarta, 1990.

Sentosa Sembiring (him), Himpunan Peraturan Perundang-Undangan Republik Indonesia Tentang Penyelesaian Sengketa Di Luar
Pengadilan (Arbitrase Dan Mediasi), Nuansa Aulia, Bandung, 2008.

Soepomo, Bab-bab Tentang Hukum Adat, Penerbitan Universitas, Jakarta, 1996.

Syamsuri, Pendidikan Agama Islam SMA Jilid 3 Untuk Kelas XII, Erlangga, Jakarta, 2007.

Tamakiran S, Asas-Asas Hukum Waris Menurut Tiga Sistem Hukum, CV. Pionir Jaya, Bandung, 2000.

Wirjono Prodjodikoro, Hukum Perdata Tentang Persetujuan Persetujuan Tertentu, Sumur Bandung, Bandung, 1991.

\section{Peraturan Perundang-undangan.}

Undang-Undang Dasar Negara Republik Indonesia 1945.

Kitab Undang-Undang Hukum Perdata.

Undang-Undang Nomor 5 Tahun 1960 Tentang Peraturan Dasar Pokok-pokok Agraria.

Undang-Undang Nomor 39 Tahun 1999 Tentang Hak Asasi Manusia.

Kompilasi Hukum Islam.

Undang-Undang Nomor 30 Tahun 1999 Tentang Arbitrase Dan Alternatif Penyelesaian Sengketa.

Peraturan Pemerintah Republik Indonesia Nomor 24 Tahun 1997 Tentang Pendaftaran Tanah. 
Peraturan Mahkamah Agung Republik Indonesia Nomor 02 Tahun 2003 Tentang Prosedur Mediasi Di Pengadilan.

Jurnal, Makalah, Internet, Dan Lainlain.

Asni Zubair, http: //rouf-artikel.blogspot. com /2012/11/penyelesaian-hukumwaris.html, Disertasi Uin Sunan Kalijaga, 2013, diunduh pada Jumat, 3 Mei, jam 14.30 WIB.

B.N Marbun, Kamus Hukum Indonesia, Edisi Kedua Direvisi, Pustaka Sinar Harapan, Jakarta, 2009.

Darwinsyah Minin, Penyelesaian Sengketa Non-Litigasi (Dasar-bentuk-TeknikProses Dan Pelaksanaan), disampaikan dalam Kuliah Umum di Fakultas Hukum Universitas Suryakancana pada tanggal 27 April 2013, Cianjur.

Dedi Mulyadi, Penyelesaian Sengketa Lingkungan Hidup Di Luar Pengadilan, Materi Kuliah ADR di Fakultas Hukum Universitas Suryakancana, Cianjur, 2011.

Dhaniasashari.blogspot.com, diunduh pada Rabu, 17 April 2013, jam 16.00 WIB.

J.C.T. Simorangkir, dkk, Kamus Hukum, Sinar Grafika, Jakarta, 2008.

Lawrence S. Clark And Peter D. Kinder, Law And Business, Third Ed, Mc. Graw Hill Inc, London, 1991.
M Juliadi Razali, Penyelesaian Sengketa Melalui Mediasi Sebagai Perwujudan Asas Peradilan Sederhana, Cepat, Dan Biaya Ringan, Disertasi UNPAR, 2011.

Shinta Kencana, Kajian Tentang Perbuatan Melawan Hukum Yang Dilakukan Ahli Waris Dalam Bentuk Pembagian Harta Warisan Tanpa Sepengetahuan Pewaris, Skripsi, Fakultas Hukum Universitas Suryakancana, Cianjur, 2012. 